\title{
Statistical Analysis of Groundwater Quality Parameters for Harrana and Azraq Basins, Jordan
}

\author{
Ali M. Obeidat ${ }^{1}$, Omar Rimawi $^{1}$, Ziad S. Abu-Hamatteh ${ }^{2 *}$ \\ ${ }^{1}$ Department of Geology, The University of Jordan, Amman, Jordan \\ ${ }^{2}$ Civil Engineering Department, Faculty of Engineering Technology, Al-Balqa Applied University, Amman, Jordan \\ Email: aalobeid2000@yahoo.com,rimawiom2@gmail.com
}

How to cite this paper: Obeidat, A. M., Rimawi, O., \& Abu-Hamatteh, Z. S. (2020). Statistical Analysis of Groundwater Quality Parameters for Harrana and Azraq Basins, Jordan. Journal of Geoscience and Environment Protection, 8, 242-261.

https://doi.org/10.4236/gep.2020.810017

Received: March 14, 2020

Accepted: October 27, 2020

Published: October 30, 2020

Copyright $\odot 2020$ by author(s) and Scientific Research Publishing Inc. This work is licensed under the Creative Commons Attribution International License (CC BY 4.0).

http://creativecommons.org/licenses/by/4.0/

\begin{abstract}
Groundwater quality parameter $\left(\mathrm{Ca}^{2+}, \mathrm{Mg}^{2+}, \mathrm{Na}^{+}, \mathrm{K}^{+}, \mathrm{Cl}^{-}, \mathrm{SO}_{4}^{2-}, \mathrm{HCO}_{3}^{-}\right.$, $\mathrm{NO}_{3}^{-}, \mathrm{B}, \mathrm{Fe}, \mathrm{Sr}, \mathrm{Mn}, \mathrm{Al}, \mathrm{Ba}, \mathrm{SiO}_{2}, \mathrm{pH}$, and $\mathrm{BTEX}$ ) relationships of 36 wells from the Harrana area and 24 wells from Azraq area are examined to classify the wells water quality. Statistical analyses of the quality parameters have been conducted. Factor analyses are applied to extract five factors from the water quality parameters of Area 1; Factor 1 accounts for more than $38 \%$ of the variance among water quality. Cations including $\mathrm{B}, \mathrm{Na}^{+}, \mathrm{Mg}^{2+}$, and $\mathrm{K}^{+}$ with anions including $\mathrm{Cl}^{-}$and $\mathrm{SO}_{4}^{2-}$ were loaded significantly. It represents the variation in the geological formations penetrated by the wells. For Azraq wells, five factors were extracted. Factor 1 accounts for more than $50 \%$ of the variance in water quality. Six of water quality parameters were loaded on Factor 1 . These parameters included cations represented by $\mathrm{B}, \mathrm{Na}^{+}$, and $\mathrm{Mg}^{2+}$ in addition to $\mathrm{Cl}^{-}$and $\mathrm{SO}_{4}^{2-}$ as anions. Cluster analysis classified the Harrana wells into three groups, i.e., cluster I included 26 wells with minimum mean concentrations of cations and anions, while cluster III included the wells with the highest concentrations in the water quality parameters. Cluster II included eight wells with intermediate concentrations between clusters I and II. The wells in the Azraq area are clustered into three groups, i.e., cluster I included seven wells with the lowest water quality, while cluster II includes 12 wells and shows the lowest concentrations of ions. Cluster III includes five wells with intermediate concentrations of ions.
\end{abstract}

\section{Keywords}

Azraq, Factor and Cluster Analysis, Groundwater, Harrana, Water Quality, Jordan 


\section{Introduction}

Generally, groundwater wells penetrating either the same aquifer or different aquifers have different water quality characteristics type (Postma \& Appelo, 1999). The groundwater quality does not depend only on natural factors such as the lithology of the aquifer, quality of recharged water, and type of interaction between water and aquifer. Human activities, which may significantly affect the quality, can alter the groundwater systems either through pollution or changing the hydrological prevailing conditions (Helena et al., 2000).

Statistical analysis approach is used to interpret the water quality of groundwater resources in the study area which is highly influenced by geological, lithological and urbanization conditions of the area (Quennel, 1956; Bender, 1974; El-Naqa et al., 2007; Obeidat \& Rimawi, 2017). The prevailing geological conditions and the lithological variation of the groundwater aquifers are highly influencing the hydrochemical characteristics of the groundwater resources, which are extremely affected by the dissolution processes of the major and minor mineralogical compositions of the aquifer (Saravanakumar \& Ranjith Kumar, 2011; Vikal, 2009). The natural variation may be attributed to the depositional environment. The variation in the hydrochemical characteristics of the groundwater can be used to explain the prevailing condition using different statistical analyses (El-Naqa et al., 2007; Obeidat \& Rimawi, 2017).

Statistical analyses including descriptive statistics of water quality parameters represented by mean, standard deviation (SD), and range are described and discussed herein. Pearson correlation matrix was conducted to find the bivariate relationships between water quality parameters. Factor analysis with varimax rotation was conducted on standardized data and factor loading of the variables was obtained. Hierarchical cluster analysis was used to group Area 1 and Area 2 wells of Harrana and Azraq, respectively. Complete linkage was used depending on Pearson distance (Helena et al., 1999; Singh et al., 2004; Zeng \& Rasmussen, 2005; Praus, 2005; Karthikeyan et al., 2017).

\section{Geologic Setting}

\subsection{Study Area}

The study Area 1 is located within Amman Governorate, Central-Eastern Jordan with an area of $1200 \mathrm{Km}^{2}$ (latitude: $31^{\circ} 45^{\prime}-31^{\circ} 25^{\prime}$ longitude: $36^{\circ} 20^{\prime}-36^{\circ} 50^{\prime}$ ), whereas the study Area 2 is located in Al Zarqa Governorate, East Jordan with an area of $300 \mathrm{Km}^{2}$ (latitude: $31^{\circ} 45^{\prime}-31^{\circ} 37^{\prime}$ longitude: $\left.37^{\circ} 02^{\prime}-37^{\circ} 15^{\prime}\right)$. The number of studied wells is 36 in Area 1 and 24 wells in Area 2 (Figure 1).

\subsection{Geology of the Study Area}

Study Area 1 is a part of the Central Desert of east Jordan as defined by Bender (1974). Wadi Dabi and Harrana area form most of Area 1, rocks exposed in this area ranges from Upper Cretaceous to Eocene in age. The bedrocks consist mainly of Balqa Group and Superficial Quaternary deposits, as it appears in the 
geologic map (Figure 2) (Quennel, 1956; Bender, 1974; Abu Qudairah, 1997; Al Hiyari \& Halasa, 2009; Al Hunjul, 1999; Fadda, 1997; Abdelhamid, 1997). Three formations of the Balqa Group can be distinguished as follows: Muwaggar Chalk Marl (MCM), Umm Rijam Chert Limestone (URC), and Shalala Formations in addition to the Azraq Formation. Many wadis, such as Wadi Harrana and Wadi Dabi (Figure 2), dissect Harrana Basin.
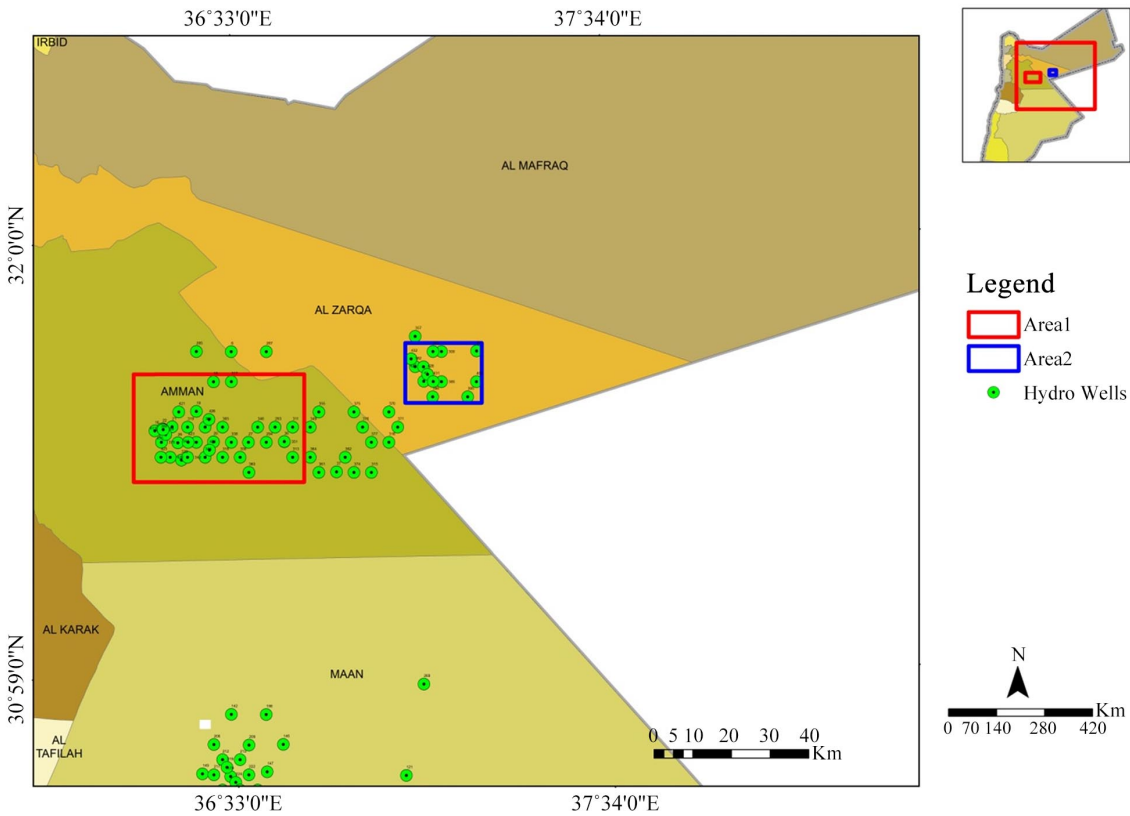

Legend



- Hydro Wells

Figure 1. Location map of observation wells in Area 1 and Area 2.

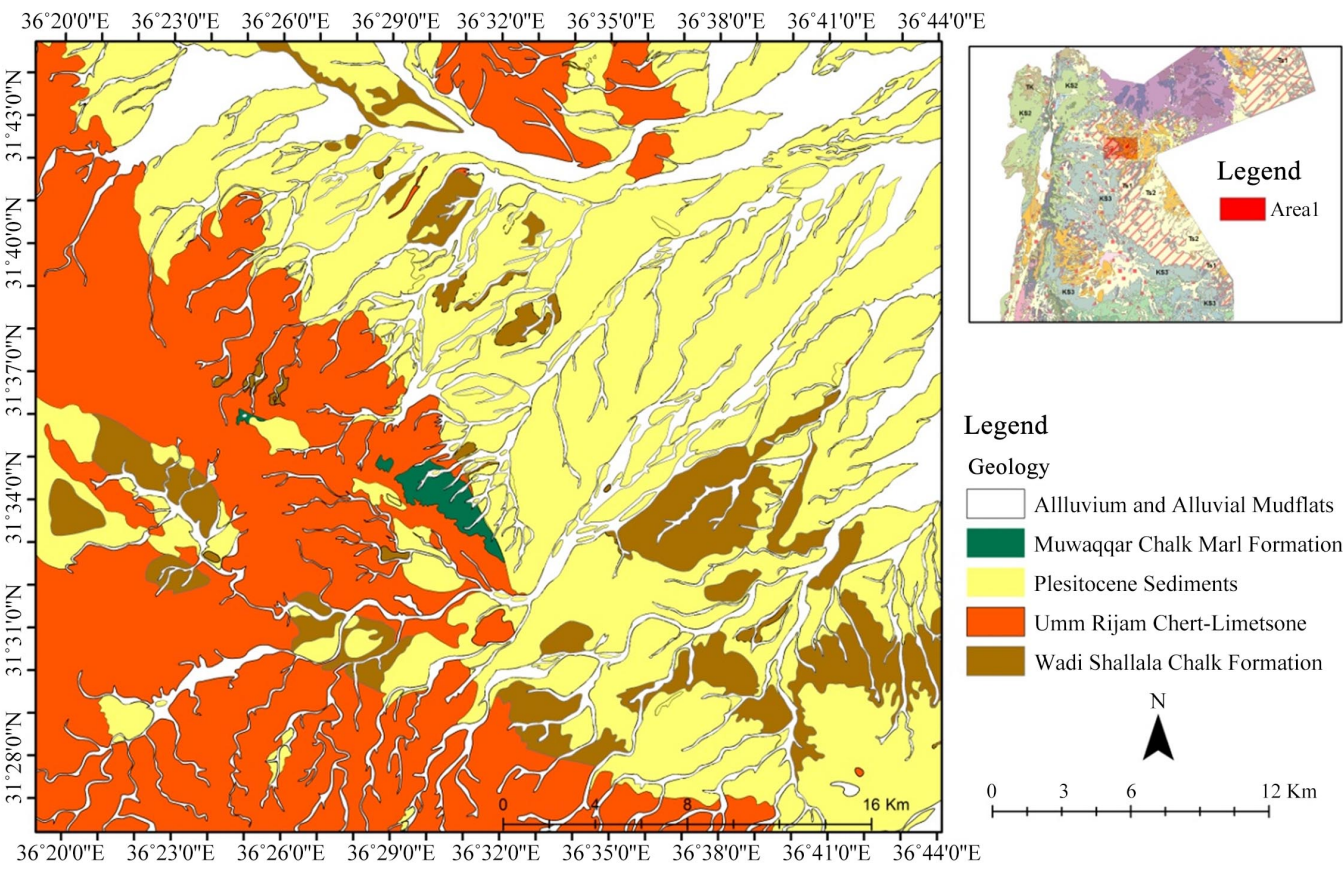

Figure 2. Geological map of the Harrana Area, study Area 1 (compiled and modified after Abu Qudairah, 1997; Al Hiyari \& Halasa, 2009; Al Hunjul, 1999; Fadda, 1997). 
The entire Azraq Basin is dissected by an extensive network of wadis, especially in the limestone areas, a graben trending northwest-southeast is the dominant structure whereas; Jabal Fuluk Fault is the main fault in the northern part of this graben. Some faults extend northwest-southeast parallel to the graben (Figure 3), whereas others have a north-northwest-south-southeast strike (El-Naqa et al., 2007) (Figure 3).

The detailed hydrogeological and hydrochemistry study was carried out by Obeidat and Rimawi (2017). The study emphasized the complexity of the hydrological setting for both basin and confirms the existence of hydrogeological seals above and below the oil shale for certain wells to apply the heating in situ technology. The bedrocks consist of Balqa Group and Superficial Quaternary deposits are classified into three Formations; Wadi Shallala Formation, Qirma Formation, Azraq Formation in addition to Pleistocene and Alluvium deposits as shown in the geologic map (Figure 4).

\section{Material and Method}

\subsection{Sample Collection}

Sixty Water samples (Area 1: 36; Area 2: 24) were collected from several groundwater wells in both areas (areas 1 and 2) for the period Dec. 2011 to July 2015 (project period). Water samples were collected after 4 hours of water pumping from each well; in plastic bottles for normal chemical analyses of major cations and anions and in $40 \mathrm{~mm}$ glass bottles for organic analyses. Directly after collection, the samples were transported to the laboratory in a refrigerator and then analyzed in the Laboratories of Water Authority Laboratories of Ministry of Water and Irrigation of Jordan, Geology Department of The University of Jordan, and $\mathrm{Al}$ control Laboratories in the UK.

\subsection{Method of Analysis}

The physical tests, which include total dissolved solids (TDS) and electrical conductivity, and the chemical tests, which include $\mathrm{pH}$, total hardness $(\mathrm{TH})$, calcium, magnesium, sodium, potassium, sulfate, nitrate, and chloride, were conducted according to the standard methods (APHA et al., 2013).

Conductivity, pH total dissolved solids and temperature PC 300 series Cyber Scan portable meter have been used to measure the various field parameters. The major cations and the major anions and traces and heavy metals have been analyzed in international laboratories following international standards procedures. The results were statically analyzed using a simple Pearson correlation to find the relationships between the parameters. Factor analysis is conducted as an attempt to explain the groundwater quality parameter variations. Statistical analysis was also used to classify the studied wells according to their water quality using complete linkage cluster analysis. The statistical results were considered significant at $\mathrm{p} \leq 0.05$. 


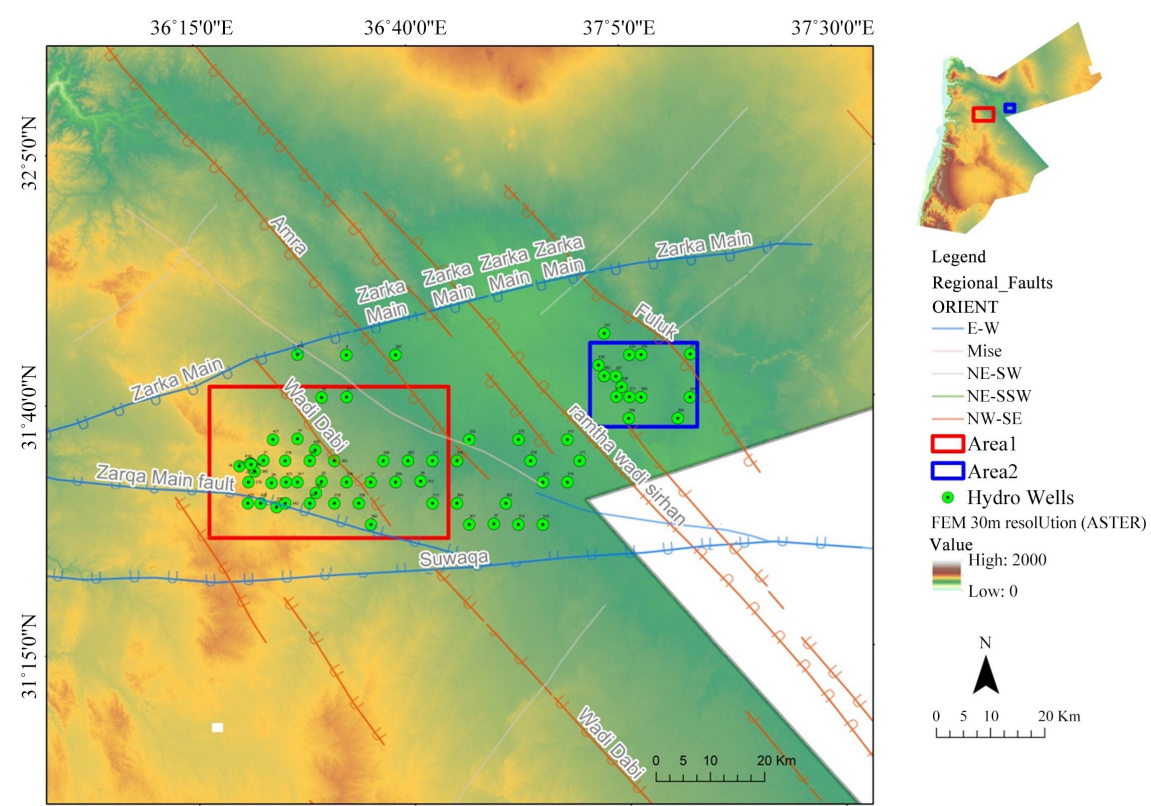

Figure 3. Regional fault system around Area 1 and Area 2-map extracted from JOSCO files (Personal Communication 2015).



Figure 4. Geological map of Azraq Area, study Area 2 (compiled and modified after Abdelhamid, 1997; Ibrahim, 1993; Fadda, 1994).

\section{Results and Discussion}

\subsection{Correlation Matrix}

\subsubsection{Correlation Matrix for Area 1 Parameters}

Table 1 shows the bivariate relationships between groundwater quality parameters in the study area. TDS shows a significant correlation with electrical conductivity, TH, sodium, calcium, magnesium, potassium, chloride, sulfate, strontium, and boron. Additionally, nitrates correlation with major and measured trace elements did not reach the significance level, while sulfate showed a significant posi- 
tive relationship with fluoride, strontium, and boron. Also, arsenic and barium did not reach a significant level, while boron showed positive significant correlation with all major elements, fluoride, and strontium. Furthermore, electrical conductivity showed a significant direct correlation with strontium and boron.

\subsubsection{Correlation Matrix for Area 2 Parameters}

Table 2 shows the bivariate relationships between groundwater quality parameters in Area 2. Ammonia showed a significant positive relationship with manganese, boron, chromium, and phosphate. Besides, manganese correlated significantly directly with chromium and phosphate. Aluminum showed a positive significant relationship with BTEX, and chromium showed a direct significant correlation with phosphate, while the later correlate directly with calcium, ammonia, and manganese. Furthermore, electrical conductivity showed a significant direct correlation with boron.

\subsection{Factor Analysis}

\subsubsection{Factor Analysis for the Water Quality Parameters of the Wells in Area 1}

Factor analysis extracted five factors from the measured water quality parameters to represent water quality variation in the study area (Table 3 ). The analysis was conducted using the rotation technique depending on Eigenvalues of 1 or more (Davis, 1973). The extracted five factors represented $76.8 \%$ of the variation in groundwater quality within the studied Area 1. The correlation of the parameters with the factors is considered significant when it exceeded the radius of the balanced circle, which is equal to 0.50 calculated from the square root of the division of the number of factors by the number of parameters (Shihab \& Al-Rawi, 2005).

Table 1. Correlation matrix for the water quality parameter in Area 1.

\begin{tabular}{|c|c|c|c|c|c|c|c|c|c|c|c|c|c|c|c|}
\hline Parameters & EC & TDS & $\mathrm{pH}$ & $\mathrm{TH}$ & $\mathrm{Ca}$ & $\mathrm{Mg}$ & $\mathrm{Na}$ & $\mathrm{K}$ & $\mathrm{Cl}$ & $\mathrm{HCO}_{3}$ & $\mathrm{SO}_{4}$ & $\mathrm{~F}$ & $\mathrm{NO}_{3}$ & $\mathrm{Sr}$ & B \\
\hline EC & 1 & $0.766^{* *}$ & -0.036 & $0.750^{* *}$ & $0.591^{* *}$ & $0.741^{* *}$ & $0.722^{* *}$ & $0.618^{* *}$ & $0.741^{* *}$ & $0.380^{*}$ & $0.515^{\star *}$ & -0.052 & -0.133 & $0.666^{* *}$ & $0.571^{* *}$ \\
\hline TDS & & 1 & 0.012 & $0.881^{* *}$ & $0.791^{* *}$ & $0.797^{\star *}$ & $0.919^{* *}$ & $0.488^{* *}$ & $0.911^{* *}$ & 0.296 & $0.583^{* *}$ & 0.115 & -0.133 & $0.777^{\star *}$ & $0.620^{* *}$ \\
\hline $\mathrm{pH}$ & & & 1 & 0.042 & 0.021 & 0.05 & 0.021 & -0.106 & 0.082 & -0.224 & -0.052 & -0.022 & -0.127 & 0.109 & -0.002 \\
\hline $\mathrm{TH}$ & & & & 1 & $0.867^{* *}$ & $0.929^{* *}$ & $0.867^{* *}$ & $0.611^{\star *}$ & $0.858^{* *}$ & $0.487^{\star *}$ & $0.633^{* *}$ & 0.007 & -0.111 & $0.858^{\star *}$ & $0.787^{* *}$ \\
\hline $\mathrm{Ca}$ & & & & & 1 & $0.619^{* *}$ & $0.828^{* *}$ & 0.297 & $0.820^{* *}$ & 0.201 & $0.730^{* *}$ & $0.351^{*}$ & -0.027 & $0.650^{* *}$ & $0.566^{* *}$ \\
\hline $\mathrm{Mg}$ & & & & & & 1 & $0.748^{* *}$ & $0.741^{* *}$ & $0.739^{* *}$ & $0.616^{* *}$ & $0.453^{* *}$ & -0.251 & -0.154 & $0.866^{* *}$ & $0.816^{* *}$ \\
\hline $\mathrm{Na}$ & & & & & & & 1 & $0.515^{\star *}$ & $0.968^{* *}$ & 0.327 & $0.623^{* *}$ & 0.23 & -0.093 & $0.704^{* *}$ & $0.556^{* *}$ \\
\hline K & & & & & & & & 1 & $0.458^{* *}$ & $0.725^{* *}$ & 0.062 & $-0.450^{* *}$ & -0.13 & $0.564^{* *}$ & $0.683^{* *}$ \\
\hline $\mathrm{Cl}$ & & & & & & & & & 1 & 0.21 & $0.709 * *$ & 0.232 & -0.084 & $0.742^{\star *}$ & $0.593^{* *}$ \\
\hline $\mathrm{HCO}_{3}$ & & & & & & & & & & 1 & -0.093 & $-0.413^{*}$ & -0.111 & 0.308 & $0.534^{* *}$ \\
\hline $\mathrm{SO}_{4}$ & & & & & & & & & & & 1 & $0.395^{*}$ & -0.035 & $0.457^{\star *}$ & $0.386^{*}$ \\
\hline F & & & & & & & & & & & & 1 & 0.304 & -0.098 & -0.16 \\
\hline $\mathrm{NO}_{3}$ & & & & & & & & & & & & & 1 & -0.128 & -0.04 \\
\hline $\mathrm{Sr}$ & & & & & & & & & & & & & & 1 & $0.746^{* *}$ \\
\hline B & & & & & & & & & & & & & & & 1 \\
\hline
\end{tabular}


Table 2. Correlation matrix for the water quality parameters in Area 2.

\begin{tabular}{|c|c|c|c|c|c|c|c|c|c|c|c|c|c|c|c|c|c|}
\hline Parameters & EC & TDS & $\mathrm{pH}$ & $\mathrm{TH}$ & $\mathrm{Ca}$ & $\mathrm{Mg}$ & $\mathrm{Na}$ & K & $\mathrm{Cl}$ & $\mathrm{HCO}_{3}$ & $\mathrm{SO}_{4}$ & $\mathrm{NO}_{3}$ & $\mathrm{NH}_{4}$ & $\mathrm{Mn}$ & B & $\mathrm{Cr}$ & $\mathrm{PO}_{4}$ \\
\hline $\mathrm{EC}$ & 1 & $0.875^{* *}$ & -0.39 & $0.728^{* *}$ & $0.662^{\star *}$ & $0.724^{* *}$ & $0.842^{* *}$ & ${ }^{*} 0.892^{* *}$ & $0.874^{* *}$ & 0.32 & $0.650^{* *}$ & * $\quad 0.25$ & 0.2 & -0.05 & $0.667^{* *}$ & -0.02 & 0.05 \\
\hline TDS & & 1 & -0.39 & $0.734^{* *}$ & $0.742^{* *}$ & $0.672^{* *}$ & $0.992^{* *}$ & ${ }^{*} 0.895^{* *}$ & $0.997^{* *}$ & 0.33 & $0.629 * *$ & * 0.18 & 0.4 & 0.16 & $0.872^{* *}$ & 0.32 & 0.24 \\
\hline $\mathrm{pH}$ & & & 1 & $-0.591^{* *}$ & $-0.597^{* *}$ & $-0.541^{* *}$ & * -0.33 & $-0.431^{*}$ & -0.4 & -0.03 & -0.33 & $-0.510^{*}$ & -0.2 & -0.29 & -0.16 & -0.14 & -0.32 \\
\hline TH & & & & 1 & $0.945^{* *}$ & $0.966^{* *}$ & $0.695^{* *}$ & ${ }^{*} 0.892^{* *}$ & $0.709^{* *}$ & -0.07 & $0.780^{* *}$ & $0.507^{*}$ & 0.11 & -0.01 & $0.441^{*}$ & 0.24 & 0.34 \\
\hline $\mathrm{Ca}$ & & & & & 1 & $0.830^{* *}$ & $0.701^{* *}$ & ${ }^{*} 0.852^{* *}$ & $0.729 * *$ & 0.04 & $0.590^{* *}$ & + $\quad 0.37$ & 0.28 & 0.21 & $0.513^{*}$ & $0.446^{*}$ & $0.515^{*}$ \\
\hline $\mathrm{Mg}$ & & & & & & 1 & $0.636^{* *}$ & ${ }^{*} 0.855^{* *}$ & $0.638^{* *}$ & -0.14 & $0.870^{* *}$ & ${ }^{*} 0.576^{* *}$ & -0.04 & -0.18 & 0.35 & 0.05 & 0.17 \\
\hline $\mathrm{Na}$ & & & & & & & 1 & $0.857^{* *}$ & $0.983^{* *}$ & 0.3 & $0.619^{* *}$ & + 0.15 & 0.39 & 0.17 & $0.878^{* *}$ & 0.33 & 0.25 \\
\hline K & & & & & & & & 1 & $0.885^{* *}$ & 0.16 & $0.731^{* *}$ & + 0.3 & 0.16 & -0.01 & $0.648^{* *}$ & 0.22 & 0.2 \\
\hline $\mathrm{Cl}$ & & & & & & & & & 1 & 0.36 & $0.581^{* *}$ & 0.16 & $0.434^{*}$ & 0.19 & $0.881^{* *}$ & 0.33 & 0.25 \\
\hline $\mathrm{HCO}_{3}$ & & & & & & & & & & 1 & -0.18 & -0.15 & $0.436^{*}$ & 0.08 & $0.495^{*}$ & 0.16 & -0.03 \\
\hline $\mathrm{SO}_{4}$ & & & & & & & & & & & 1 & $0.533^{\star *}$ & -0.22 & -0.37 & 0.37 & -0.12 & -0.11 \\
\hline $\mathrm{NO}_{3}$ & & & & & & & & & & & & 1 & -0.27 & -0.28 & 0.02 & -0.19 & 0.01 \\
\hline $\mathrm{NH}_{4}$ & & & & & & & & & & & & & 1 & $0.635^{* *}$ & $0.594^{* *}$ & $0.456^{*}$ & $0.474^{*}$ \\
\hline Mn & & & & & & & & & & & & & & 1 & 0.27 & $0.634^{* *}$ & ${ }^{*} 0.681^{* *}$ \\
\hline B & & & & & & & & & & & & & & & 1 & 0.4 & 0.3 \\
\hline $\mathrm{Cr}$ & & & & & & & & & & & & & & & & 1 & $0.831^{* *}$ \\
\hline $\mathrm{PO}_{4}$ & & & & & & & & & & & & & & & & & 1 \\
\hline
\end{tabular}

The first factor (Factor 1) represents $38.79 \%$ of the total variance. This factor shows a significant correlation with magnesium, sulfate, chloride, sodium, calcium, and boron ions also the TH and the TDS and electric conductivity were loaded significantly (Table 3 ).

Factor 2 represents $15.718 \%$ of the total variance in groundwater quality within the study area. Bicarbonate, potassium, boron, and fluoride were loaded on it significantly (Figure 5(a)). This figure also shows a direct strong correlation between potassium ion and bicarbonate as found in the correlation matrix (Table 3). Also, the figure exhibits a weak correlation between bicarbonate and potassium from 1 side from one side versus fluoride from the other side according to the angle between the parameters vectors which is weak when it is about 90 degrees, strong when it is small, and inverse when reaching 180 degrees and around it.

Factor 3 represents $8.228 \%$ of the total variance in groundwater quality (Table 3). Nitrate, barium, and silica were loaded significantly on it (Figure 5(b)). The figure shows a strong correlation between nitrate and barium ions and both ions show a negative correlation with silica. 
Factor 4 represents $7.335 \%$ of the total variance in groundwater quality of the studied area (Table 3), arsenic, and $\mathrm{pH}$ loaded significantly (Figure 5(c)). The Figure shows a strong correlation between nitrate and $\mathrm{pH}$, and a weak negative correlation with sulfate.

Factor 5 represents $6.772 \%$ of the total variance in groundwater quality, $\mathrm{Mn}$ and Fe loaded significantly (Figure 5(d)). This figure shows the inverse correlation between manganese and iron and both have a weak correlation with sulfate.

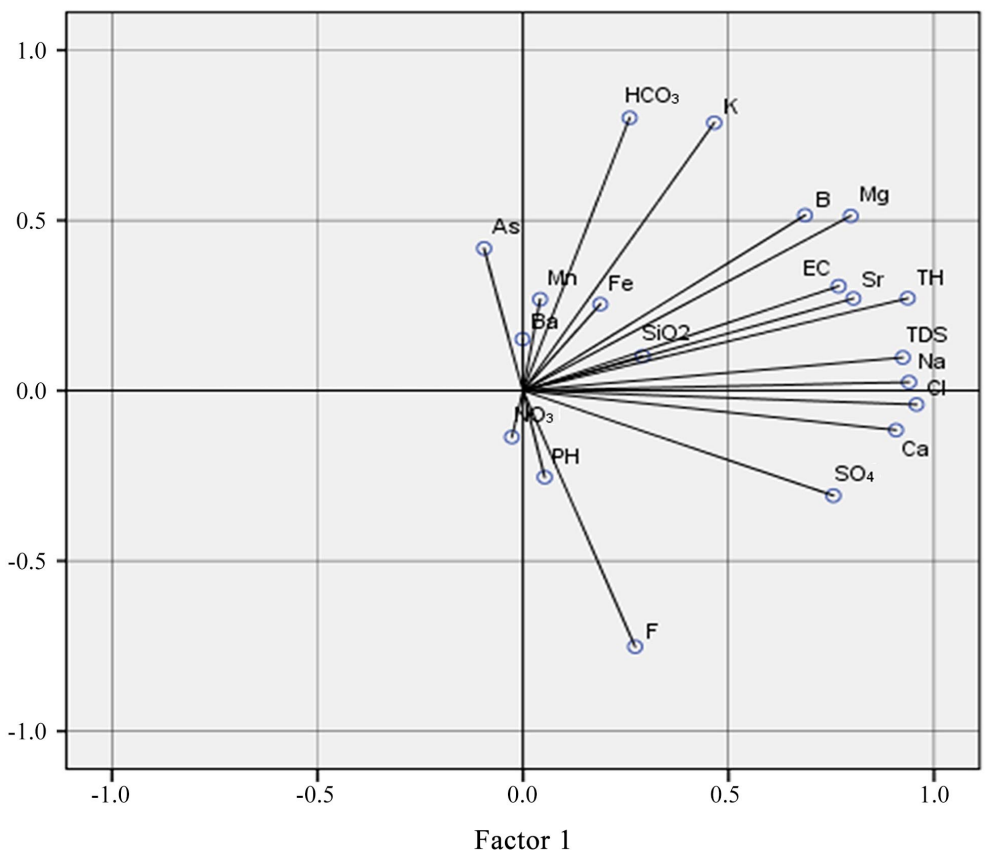

(a) Factor 1 and Factor 2

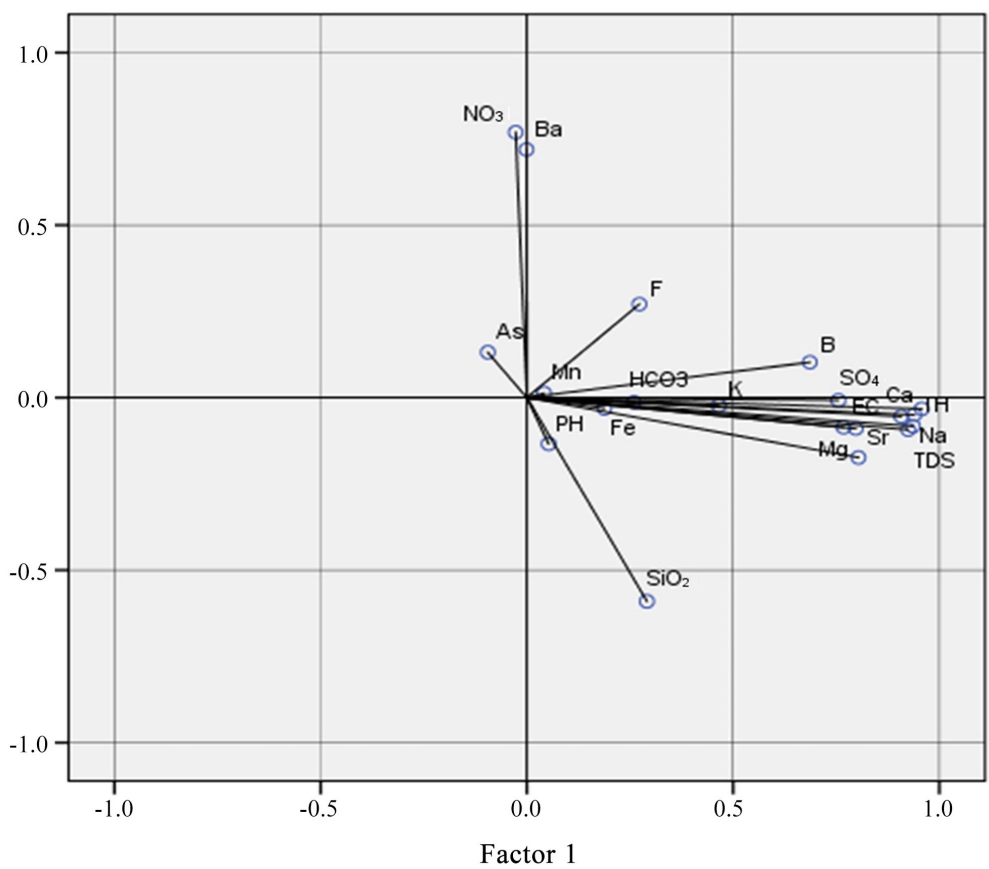

(b) Factor 1 and Factor 3 


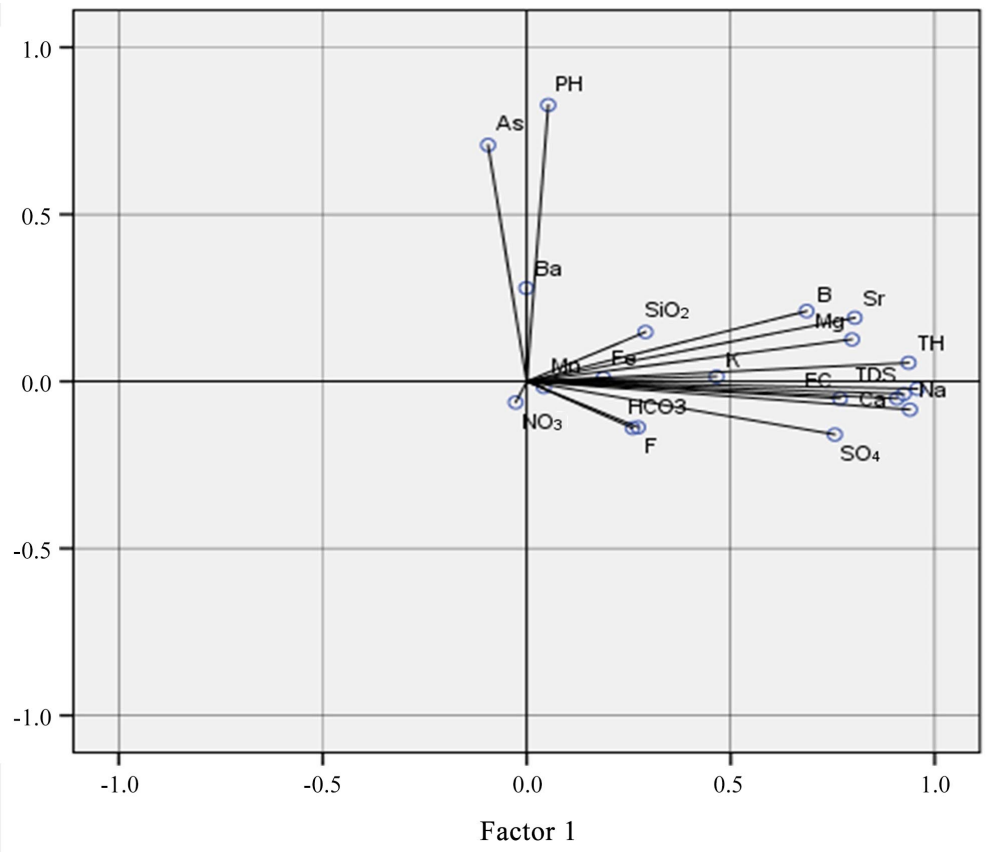

(c) Factor 1 and Factor 4

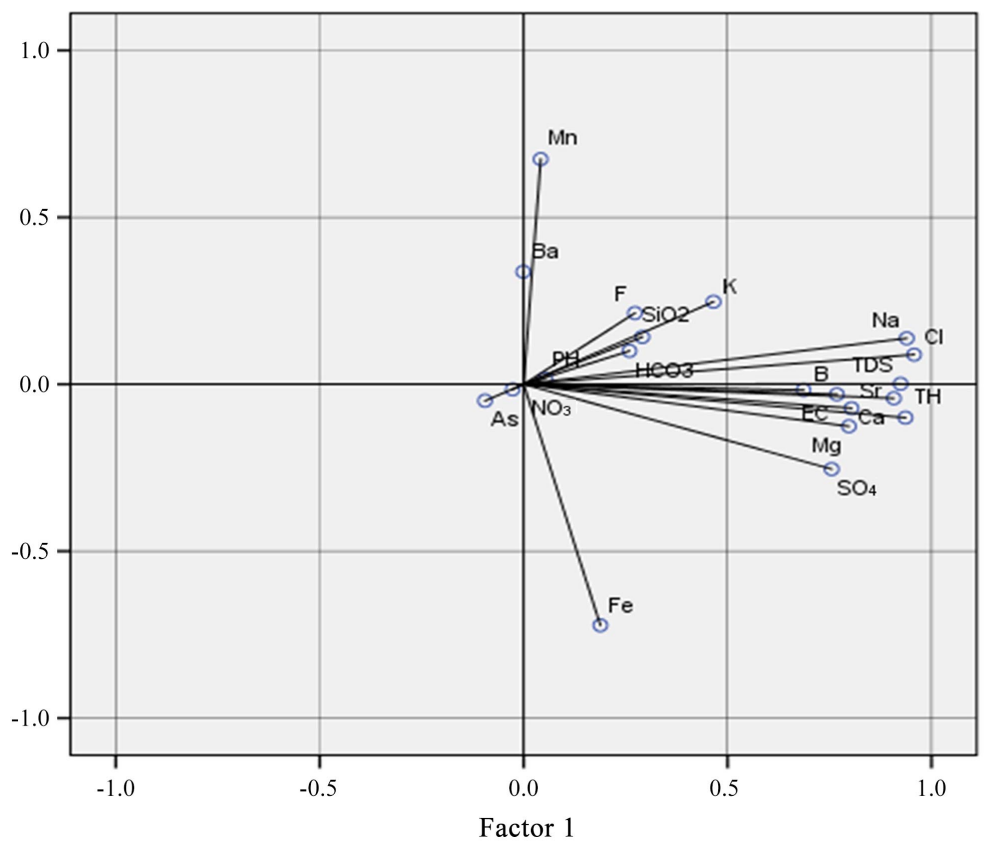

(d) Factor 1 and Factor 5

Figure 5. Factor analysis for groundwater wells in Area 1.

\subsubsection{Factor Analysis for the Water Quality Parameters of the Wells in Area 2}

Table 4 shows the five factors of the factor analysis extracts according to Eigenvalues $(>1)$ for Area 2 wells. The first factor accounts for almost half the variability in water quality, whereas the second factor assists in describing water quality information of Area 2 wells within 20\%. Cations including B, $\mathrm{Na}, \mathrm{Mg}, \mathrm{Ca}$, and $\mathrm{K}$ with anions including $\mathrm{Cl}, \mathrm{SO}_{4}$, and $\mathrm{NO}_{3}$ were loaded significantly on Factor 1. 
Table 3. The loadings of the Varimax rotation factor analysis of groundwater wells in Area 1.

\begin{tabular}{|c|c|c|c|c|c|}
\hline \multirow{2}{*}{ Parameters } & \multicolumn{5}{|c|}{ Factor } \\
\hline & 1 & 2 & 3 & 4 & 5 \\
\hline $\mathrm{Cl} \mathrm{mg/L}$ & 0.957 & -0.041 & -0.032 & -0.022 & 0.089 \\
\hline $\mathrm{Na} \mathrm{mg} / \mathrm{L}$ & 0.939 & 0.025 & -0.05 & -0.084 & 0.138 \\
\hline $\mathrm{TH} \mathrm{mg} / \mathrm{L}$ & 0.936 & 0.271 & -0.083 & 0.056 & -0.1 \\
\hline TDS mg/L & 0.924 & 0.097 & -0.093 & -0.038 & 0.001 \\
\hline $\mathrm{Ca} \mathrm{mg} / \mathrm{L}$ & 0.908 & -0.116 & -0.055 & -0.051 & -0.042 \\
\hline Sr mg/L & 0.804 & 0.271 & -0.174 & 0.19 & -0.072 \\
\hline $\mathrm{Mg} \mathrm{mg/L}$ & 0.797 & 0.513 & -0.09 & 0.126 & -0.126 \\
\hline $\mathrm{EC} \mu \mathrm{S} / \mathrm{cm}$ & 0.768 & 0.307 & -0.086 & -0.051 & -0.03 \\
\hline $\mathrm{SO}_{4} \mathrm{mg} / \mathrm{L}$ & 0.755 & -0.308 & -0.008 & -0.159 & -0.254 \\
\hline B mg/L & 0.686 & 0.515 & 0.103 & 0.21 & -0.017 \\
\hline $\mathrm{HCO}_{3} \mathrm{mg} / \mathrm{L}$ & 0.26 & 0.801 & -0.013 & -0.14 & 0.1 \\
\hline $\mathrm{K} \mathrm{mg/L}$ & 0.465 & 0.787 & -0.024 & 0.014 & 0.247 \\
\hline $\mathrm{F} \mathrm{mg/L}$ & 0.273 & -0.752 & 0.271 & -0.137 & 0.213 \\
\hline $\mathrm{NO}_{3} \mathrm{mg} / \mathrm{L}$ & -0.027 & -0.136 & 0.769 & -0.063 & -0.016 \\
\hline $\mathrm{Ba} \mathrm{mg} / \mathrm{L}$ & -0.001 & 0.151 & 0.719 & 0.279 & 0.337 \\
\hline $\mathrm{SiO}_{2} \mathrm{mg} / \mathrm{L}$ & 0.291 & 0.101 & -0.59 & 0.148 & 0.142 \\
\hline $\mathrm{pH}$ & 0.053 & -0.254 & -0.134 & 0.827 & 0.017 \\
\hline As $\mathrm{mg} / \mathrm{L}$ & -0.095 & 0.418 & 0.131 & 0.708 & -0.049 \\
\hline $\mathrm{Fe} \mathrm{mg} / \mathrm{L}$ & 0.188 & 0.254 & -0.031 & 0.009 & -0.722 \\
\hline $\mathrm{Mn} \mathrm{mg} / \mathrm{L}$ & 0.042 & 0.268 & 0.013 & -0.017 & 0.674 \\
\hline Eigen value & 7.758 & 3.144 & 1.646 & 1.467 & 1.354 \\
\hline$\%$ Variance & 38.791 & 15.718 & 8.228 & 7.335 & 6.772 \\
\hline \%Cumulative & 38.791 & 54.509 & 62.737 & 70.072 & 76.844 \\
\hline
\end{tabular}

Figure 6(a) indicates a strong relationship between the cations and anions. The $\mathrm{pH}$ showed an inverse relationship with anions and cations. Phosphate chromium and manganese loaded significantly on Factor 2.

Factor 3 denoted $15 \%$ of the total variance in groundwater quality within the study area. Alkalinity, ammonia, and boron were loaded on it significantly (Figure 6(b)). The Figure also shows a direct strong correlation between ammonia and alkalinity as found in the correlation matrix (Table 2). The Figure exhibits a weak correlation between ammonia, lead, and alkalinity from one side versus nitrate chloride.

Factor 4 represents the geology of the studied area with $10.0 \%$ of the total variance in groundwater quality (Table 4). Arsenic and $\mathrm{pH}$ were loaded significantly on it. The weak correlation was observed between arsenic and nitrate (Figure 6(c)). 
Table 4. The loadings of the Varimax rotation factor analysis of groundwater wells in Area 2.

\begin{tabular}{|c|c|c|c|c|c|}
\hline \multirow{2}{*}{ Parameters } & \multicolumn{5}{|c|}{ Factors } \\
\hline & 1 & 2 & 3 & 4 & 5 \\
\hline $\mathrm{Mg} \mathrm{mg} / \mathrm{L}$ & 0.946 & -0.034 & -0.208 & -0.141 & -0.037 \\
\hline $\mathrm{TH} \mathrm{mg} / \mathrm{L}$ & 0.943 & 0.145 & -0.115 & -0.19 & -0.113 \\
\hline $\mathrm{K} \mathrm{mg/L}$ & 0.938 & 0.069 & 0.19 & -0.008 & 0.034 \\
\hline $\mathrm{SO}_{4} \mathrm{mg} / \mathrm{L}$ & 0.875 & -0.26 & -0.193 & 0.047 & 0.126 \\
\hline $\mathrm{Ca} \mathrm{mg} / \mathrm{L}$ & 0.848 & 0.358 & 0.014 & -0.234 & -0.199 \\
\hline TDS mg/L & 0.845 & 0.179 & 0.463 & 0.063 & 0.078 \\
\hline $\mathrm{EC} \mu \mathrm{S} / \mathrm{cm}$ & 0.841 & -0.079 & 0.367 & 0.025 & 0.227 \\
\hline $\mathrm{Na} \mathrm{mg} / \mathrm{L}$ & 0.819 & 0.192 & 0.457 & 0.128 & 0.053 \\
\hline $\mathrm{Cl} \mathrm{mg/L}$ & 0.817 & 0.194 & 0.508 & 0.039 & 0.098 \\
\hline $\mathrm{NO}_{3} \mathrm{mg} / \mathrm{L}$ & 0.507 & -0.219 & -0.369 & -0.389 & -0.004 \\
\hline $\mathrm{PO}_{4} \mathrm{mg} / \mathrm{L}$ & 0.194 & 0.899 & -0.093 & -0.021 & -0.161 \\
\hline $\mathrm{Mn} \mathrm{mg} / \mathrm{L}$ & -0.132 & 0.893 & 0.214 & -0.112 & 0.117 \\
\hline $\mathrm{Cr} \mathrm{mg} / \mathrm{L}$ & 0.143 & 0.855 & 0.106 & 0.123 & -0.196 \\
\hline $\mathrm{HCO}_{3} \mathrm{mg} / \mathrm{L}$ & 0.021 & -0.049 & 0.808 & 0.04 & -0.044 \\
\hline B mg/L & 0.579 & 0.247 & 0.679 & 0.158 & 0.001 \\
\hline $\mathrm{NH}_{4} \mathrm{mg} / \mathrm{L}$ & 0.058 & 0.55 & 0.651 & -0.077 & -0.137 \\
\hline As $\mathrm{mg} / \mathrm{L}$ & 0.055 & 0.07 & 0.043 & 0.908 & -0.035 \\
\hline $\mathrm{pH}$ & -0.476 & -0.273 & 0.042 & 0.672 & -0.186 \\
\hline $\mathrm{Al} \mathrm{mg/L}$ & 0.155 & -0.08 & 0.107 & -0.272 & 0.758 \\
\hline BTEX mg/L & -0.098 & 0.26 & 0.214 & -0.3 & -0.75 \\
\hline $\mathrm{Fe} \mathrm{mg} / \mathrm{L}$ & -0.387 & 0.053 & -0.069 & -0.306 & 0.457 \\
\hline Eigenvalues & 7.994 & 3.244 & 2.751 & 1.881 & 1.62 \\
\hline$\%$ of Variance & 38.065 & 15.447 & 13.1 & 8.959 & 7.717 \\
\hline Cumulative \% & 38.065 & 53.512 & 66.612 & 75.571 & 83.288 \\
\hline
\end{tabular}

Factor 5 represented the lowest percentage of variation in groundwater quality with $10 \%$. Organic and Aluminum was loaded significantly on it, which inversely correlated with each other (Figure 6(d)).

\subsection{Cluster Analysis}

\subsubsection{Cluster Analysis for the Water Quality Parameters of Area 1}

Figure 7 shows the results of cluster analysis for the water quality of the deep wells of Area 1. Three clusters were obtained from this analysis. Cluster I had the largest number of wells of 26 with $72.2 \%$ and it includes two sub-clusters. Cluster II includes 8 wells (No. 31, 33, 26, 34, 27, 30, 29, and 32) with $22.2 \%$ of the studied wells and it includes two sub-clusters. The smallest cluster III includes two wells only (No. 35 and 36) and it represents 5.55\% of the studied wells. 


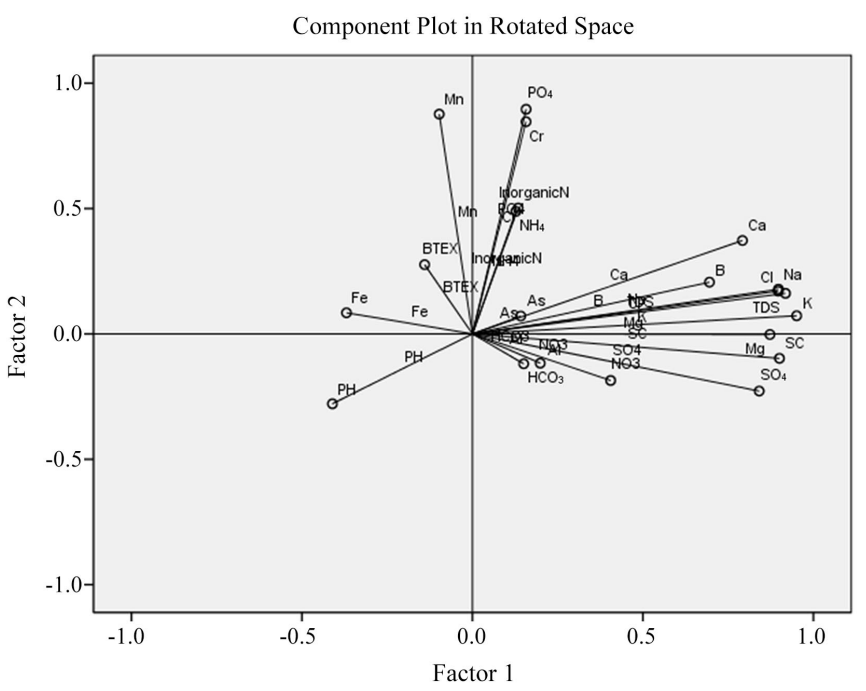

(a) Factor 1 and Factor 2

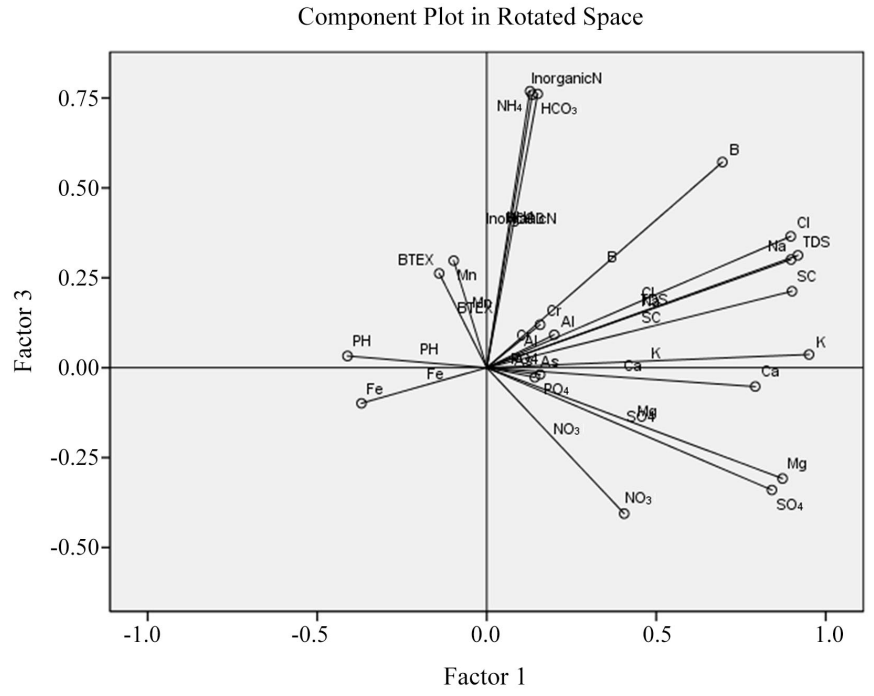

(b) Factor 1 and Factor 3



(c) Factor 1 and Factor 4 


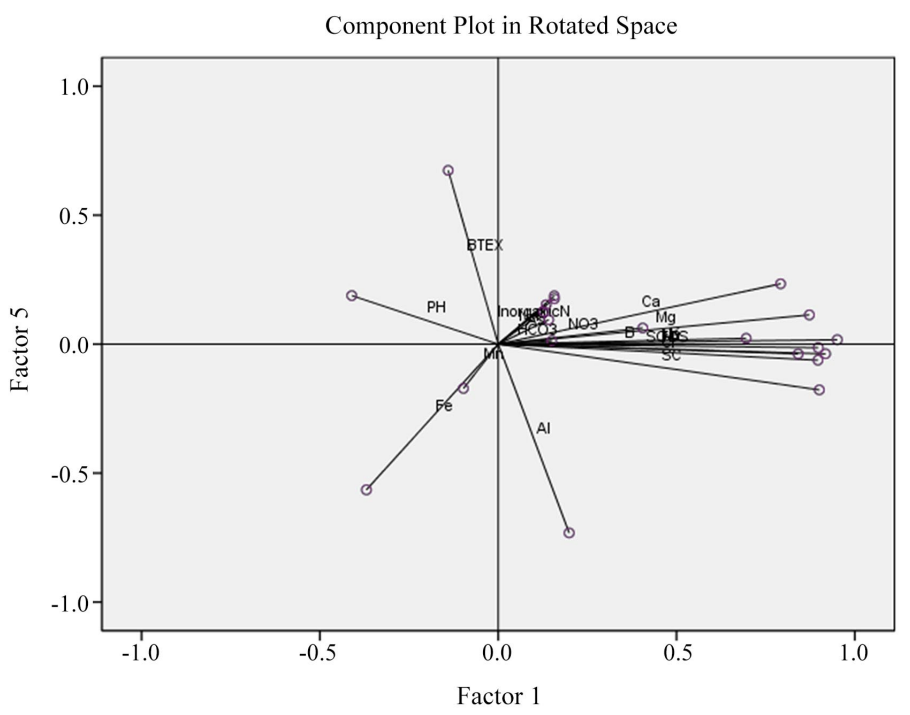

(d) Factor 1 and Factor 5

Figure 6. Factor analysis for groundwater wells in Area 2.



Figure 7. Hierarchical dendrogram cluster analysis of water quality parameters of the studied wells in Area 1.

Table 5 shows that the water quality of the wells of Cluster I recorded the lowest mean concentrations of cations, anions, TDS, TH, and conductivity, while the highest concentration of these parameters was recorded in Cluster III wells. On the other hand, Cluster II wells recorded intermediate mean concentrations between Cluster I and III. The distribution of Harrana wells and the clusters are shown in Figure 7. 


\subsubsection{Cluster Analysis for the Water Quality Parameters of Area 2}

Table 6 shows that the water quality of the wells of cluster II recorded the lowest mean concentrations of cations, anions, TDS, TH, and conductivity, while the highest concentration of these parameters was recorded in cluster I wells.

Table 5. The characteristics of the groundwater quality of the groups of wells extracted from cluster analysis for Area 1.

\begin{tabular}{|c|c|c|c|c|c|c|}
\hline Parameters & Cluster & No. of wells & Mean & SD & Min. & Max. \\
\hline & I & 26 & 1782.543 & 523.728 & 710 & 2489.779 \\
\hline \multirow[t]{3}{*}{$\mathrm{EC} \mu \mathrm{S} / \mathrm{cm}$} & II & 8 & 3498.645 & 376.958 & 2887 & 4099.159 \\
\hline & III & 2 & 5195 & 417.193 & 4900 & 5490 \\
\hline & I & 26 & 1249.751 & 382.415 & 659.305 & 2220 \\
\hline \multirow[t]{3}{*}{ TDS mg/L } & II & 8 & 1854.715 & 254.942 & 1594.12 & 2382.97 \\
\hline & III & 2 & 3553.15 & 78.418 & 3497.7 & 3608.6 \\
\hline & I & 26 & 7.311 & 0.298 & 6.84 & 7.92 \\
\hline \multirow[t]{3}{*}{$\mathrm{pH}$} & II & 8 & 7.253 & 0.213 & 6.95 & 7.63 \\
\hline & III & 2 & 7.46 & 0.028 & 7.44 & 7.48 \\
\hline & I & 26 & 540.858 & 172.926 & 236.36 & 939.88 \\
\hline \multirow[t]{3}{*}{$\mathrm{TH} \mathrm{mg} / \mathrm{L}$} & II & 8 & 798.336 & 128.318 & 647.72 & 998.852 \\
\hline & III & 2 & 1561.63 & 26.517 & 1542.88 & 1580.38 \\
\hline & I & 26 & 129.608 & 42.693 & 69 & 226 \\
\hline \multirow[t]{3}{*}{$\mathrm{Ca} \mathrm{mg} / \mathrm{L}$} & II & 8 & 187 & 50.725 & 97.8 & 270.2 \\
\hline & III & 2 & 255.5 & 10.607 & 248 & 263 \\
\hline & I & 26 & 52.631 & 20.41 & 15.5 & 99 \\
\hline \multirow[t]{3}{*}{$\mathrm{Mg} \mathrm{mg/L}$} & II & 8 & 80.3 & 27.355 & 44.7 & 114 \\
\hline & III & 2 & 224 & 0 & 224 & 224 \\
\hline & I & 26 & 200.869 & 97.528 & 47.5 & 428.5 \\
\hline \multirow[t]{3}{*}{$\mathrm{Na} \mathrm{mg} / \mathrm{L}$} & II & 8 & 374.575 & 86.116 & 289.2 & 498.4 \\
\hline & III & 2 & 664.5 & 23.335 & 648 & 681 \\
\hline & I & 26 & 7.415 & 4.935 & 1.7 & 28.6 \\
\hline \multirow[t]{3}{*}{$\mathrm{K} \mathrm{mg} / \mathrm{L}$} & II & 8 & 15.488 & 12.61 & 2.2 & 35.8 \\
\hline & III & 2 & 31.4 & 1.131 & 30.6 & 32.2 \\
\hline & I & 26 & 360.127 & 209.463 & 50.9 & 892.4 \\
\hline \multirow[t]{3}{*}{$\mathrm{Cl} \mathrm{mg/L}$} & II & 8 & 780.2 & 295.042 & 526.6 & 1351 \\
\hline & III & 2 & 1674 & 8.485 & 1668 & 1680 \\
\hline & I & 26 & 326.365 & 85.872 & 182.4 & 492.9 \\
\hline \multirow[t]{3}{*}{$\mathrm{HCO}_{3} \mathrm{mg} / \mathrm{L}$} & II & 8 & 409.413 & 195.888 & 203.7 & 783 \\
\hline & III & 2 & 499.5 & 17.678 & 487 & 512 \\
\hline & I & 26 & 228.338 & 77.188 & 39.4 & 332.8 \\
\hline \multirow[t]{2}{*}{$\mathrm{SO}_{4} \mathrm{mg} / \mathrm{L}$} & II & 8 & 336.388 & 203.781 & 33.5 & 695 \\
\hline & III & 2 & 454 & 49.497 & 419 & 489 \\
\hline
\end{tabular}


A. M. Obeidat et al.

\section{Continued}

\begin{tabular}{|c|c|c|c|c|c|c|}
\hline & I & 26 & 1.796 & 0.531 & 0.7 & 2.8 \\
\hline \multirow[t]{3}{*}{ F mg/L } & II & 8 & 1.9 & 0.901 & 0.7 & 3 \\
\hline & III & 2 & 1.2 & 0 & 1.2 & 1.2 \\
\hline & I & 26 & 2.638 & 9.037 & 0.2 & 46.5 \\
\hline \multirow{3}{*}{$\mathrm{NO}_{3} \mathrm{mg} / \mathrm{L}$} & II & 8 & 1.013 & 0.868 & 0.2 & 2.7 \\
\hline & III & 2 & 0.45 & 0.354 & 0.2 & 0.7 \\
\hline & I & 26 & 5.373 & 4.594 & 0.3 & 17.4 \\
\hline \multirow[t]{3}{*}{$\mathrm{Fe} \mathrm{mg} / \mathrm{L}$} & II & 8 & 10.475 & 14.992 & 0.1 & 45.1 \\
\hline & III & 2 & 9.85 & 2.192 & 8.3 & 11.4 \\
\hline & I & 26 & 23.546 & 13.532 & 5.5 & 51.9 \\
\hline \multirow[t]{3}{*}{$\mathrm{SiO}_{2} \mathrm{mg} / \mathrm{L}$} & II & 8 & 25.975 & 15.03 & 2.1 & 42.6 \\
\hline & III & 2 & 35.3 & 0.566 & 34.9 & 35.7 \\
\hline & I & 26 & 5.932 & 5.261 & 0.18 & 23.2 \\
\hline \multirow[t]{3}{*}{ Sr mg/L } & II & 8 & 10.223 & 8.64 & 0.18 & 24.3 \\
\hline & III & 2 & 64.1 & 1.414 & 63.1 & 65.1 \\
\hline & I & 26 & 0.356 & 0.568 & 0.05 & 2.96 \\
\hline \multirow[t]{3}{*}{$\mathrm{Mn} \mathrm{mg} / \mathrm{L}$} & II & 8 & 10.147 & 26.626 & 0.1 & 76 \\
\hline & III & 2 & 0.725 & 0.163 & 0.61 & 0.84 \\
\hline & I & 26 & 0.021 & 0.016 & 0.01 & 0.07 \\
\hline \multirow[t]{3}{*}{$\mathrm{Al} \mathrm{mg/L}$} & II & 8 & 0.104 & 0.253 & 0.01 & 0.73 \\
\hline & III & 2 & 0.7 & 0 & 0.7 & 0.7 \\
\hline & I & 26 & 0.008 & 0.003 & 0.003 & 0.019 \\
\hline \multirow[t]{3}{*}{ As $\mathrm{mg} / \mathrm{L}$} & II & 8 & 0.007 & 0.003 & 0.003 & 0.01 \\
\hline & III & 2 & 0.01 & 0 & 0.01 & 0.01 \\
\hline & I & 26 & 0.461 & 0.184 & 0.2 & 0.95 \\
\hline \multirow[t]{3}{*}{ B mg/L } & II & 8 & 0.633 & 0.333 & 0.001 & 1.07 \\
\hline & III & 2 & 1.41 & 0.113 & 1.33 & 1.49 \\
\hline & I & 26 & 0.2 & 0.211 & 0.03 & 0.859 \\
\hline \multirow[t]{3}{*}{$\mathrm{Ba} \mathrm{mg} / \mathrm{L}$} & II & 8 & 0.159 & 0.134 & 0.02 & 0.4 \\
\hline & III & 2 & 0.215 & 0.021 & 0.2 & 0.23 \\
\hline & I & 26 & 0.028 & 0 & 0.028 & 0.028 \\
\hline \multirow[t]{2}{*}{ BTEX mg/L } & II & 8 & 0.028 & 0 & 0.028 & 0.028 \\
\hline & III & 2 & 0.055 & 0.001 & 0.054 & 0.055 \\
\hline
\end{tabular}


Table 6. The characteristics of the groundwater quality of the groups of wells extracted from cluster analysis for Area 2.

\begin{tabular}{|c|c|c|c|c|c|c|}
\hline Parameters & Cluster & No of Wells & Mean & $\mathrm{SD}$ & Min. & Max. \\
\hline & I & 7 & $150,186.5$ & $22,124.17$ & 111,330 & 180,673 \\
\hline \multirow[t]{3}{*}{$\mathrm{EC} \mu \mathrm{S} / \mathrm{cm}$} & II & 12 & $19,318.81$ & 9422.747 & 5286 & 39,060 \\
\hline & III & 5 & $78,748.85$ & $20,911.42$ & $55,869.4$ & $107,003.5$ \\
\hline & I & 7 & $94,596.2$ & 9859.18 & $81,806.5$ & 107,085 \\
\hline \multirow[t]{3}{*}{ TDS mg/L } & II & 12 & $20,644.48$ & $20,585.73$ & 5016.3 & $74,117.1$ \\
\hline & III & 5 & $73,815.62$ & $10,847.02$ & 63,499 & $88,186.5$ \\
\hline & I & 7 & 7.041 & 0.505 & 6.41 & 7.86 \\
\hline \multirow[t]{3}{*}{$\mathrm{pH}$} & II & 12 & 7.428 & 0.42 & 6.85 & 8.36 \\
\hline & III & 5 & 6.95 & 0.46 & 6.41 & 7.6 \\
\hline & I & 7 & 8014.504 & 2909.035 & 4268.68 & $11,733.92$ \\
\hline \multirow[t]{3}{*}{$\mathrm{TH} \mathrm{mg} / \mathrm{L}$} & II & 12 & 2343.153 & 1962.212 & 712.036 & 6863.4 \\
\hline & III & 5 & 5944.395 & 3587.12 & 39.336 & 9830.08 \\
\hline & I & 7 & 1409.129 & 348.374 & 984 & 1865.6 \\
\hline \multirow[t]{3}{*}{$\mathrm{Ca} \mathrm{mg} / \mathrm{L}$} & II & 12 & 483.333 & 524.572 & 136 & 1600 \\
\hline & III & 5 & 1206.92 & 692.916 & 7 & 1750 \\
\hline & I & 7 & 1090.214 & 505.174 & 439 & 1716 \\
\hline \multirow[t]{3}{*}{$\mathrm{Mg} \mathrm{mg/L}$} & II & 12 & 275.44 & 171.99 & 90.3 & 695 \\
\hline & III & 5 & 710.46 & 520.4 & 5.3 & 1459 \\
\hline & I & 7 & $31,941.83$ & 4450.835 & 26,786 & 40,200 \\
\hline \multirow[t]{3}{*}{$\mathrm{Na} \mathrm{mg} / \mathrm{L}$} & II & 12 & 6862.5 & 7360.474 & 1510 & 26,600 \\
\hline & III & 5 & $26,447.18$ & 5277.623 & 21,200 & 33,300 \\
\hline & I & 7 & 1354.2 & 152.584 & 1170 & 1650 \\
\hline \multirow[t]{3}{*}{$\mathrm{K} \mathrm{mg} / \mathrm{L}$} & II & 12 & 239.475 & 254.037 & 45.9 & 901 \\
\hline & III & 5 & 744.66 & 442.363 & 25.3 & 1140 \\
\hline & I & 7 & $55,790.73$ & 7150.548 & $46,420.3$ & 65,500 \\
\hline \multirow[t]{3}{*}{$\mathrm{Cl} \mathrm{mg} / \mathrm{L}$} & II & 12 & $12,181.67$ & $12,201.22$ & 2910 & 43,700 \\
\hline & III & 5 & $42,794.02$ & 6080.014 & 36,800 & 51,600 \\
\hline & I & 7 & 1368.3 & 1346.828 & 594.1 & 4330 \\
\hline \multirow[t]{3}{*}{$\mathrm{HCO}_{3} \mathrm{mg} / \mathrm{L}$} & II & 12 & 888.083 & 549.329 & 470 & 2380 \\
\hline & III & 5 & 980.36 & 244.034 & 636.8 & 1320 \\
\hline & I & 7 & 2325.971 & 1578.12 & 307 & 4200 \\
\hline \multirow[t]{3}{*}{$\mathrm{SO}_{4} \mathrm{mg} / \mathrm{L}$} & II & 12 & 208.6 & 236.207 & 2 & 781 \\
\hline & III & 5 & 1396.6 & 1453.369 & 2 & 3491 \\
\hline & I & 7 & 1.329 & 2.766 & 0.2 & 7.6 \\
\hline \multirow[t]{2}{*}{$\mathrm{NO}_{3} \mathrm{mg} / \mathrm{L}$} & II & 12 & 0.417 & 0.244 & 0.3 & 1.1 \\
\hline & III & 5 & 1.8 & 3.298 & 0.3 & 7.7 \\
\hline
\end{tabular}




\section{Continued}

\begin{tabular}{|c|c|c|c|c|c|c|}
\hline & I & 7 & 3.279 & 8.564 & 0.004 & 22.7 \\
\hline \multirow[t]{3}{*}{$\mathrm{Fe} \mathrm{mg} / \mathrm{L}$} & II & 12 & 11.989 & 24.199 & 0.004 & 85.4 \\
\hline & III & 5 & 2.986 & 6.549 & 0.004 & 14.7 \\
\hline & I & 7 & 81.686 & 45.923 & 35 & 166 \\
\hline \multirow[t]{3}{*}{$\mathrm{NH}_{4} \mathrm{mg} / \mathrm{L}$} & II & 12 & 61.792 & 58.898 & 9.5 & 194 \\
\hline & III & 5 & 2.986 & 6.549 & 0.004 & 14.7 \\
\hline & I & 7 & 2.579 & 2.616 & 0.336 & 7.42 \\
\hline \multirow[t]{3}{*}{$\mathrm{Mn} \mathrm{mg} / \mathrm{L}$} & II & 12 & 3.283 & 2.873 & 0.336 & 8.46 \\
\hline & III & 5 & 5.811 & 5.223 & 0.336 & 14.5 \\
\hline & I & 7 & 0.038 & 0.01 & 0.022 & 0.055 \\
\hline \multirow[t]{3}{*}{$\mathrm{Al} \mathrm{mg/L}$} & II & 12 & 0.03 & 0.009 & 0.013 & 0.037 \\
\hline & III & 5 & 0.032 & 0.012 & 0.01 & 0.037 \\
\hline & I & 7 & 0.017 & 0.022 & 0.001 & 0.05 \\
\hline \multirow[t]{3}{*}{ As $\mathrm{mg} / \mathrm{L}$} & II & 12 & 0.014 & 0.016 & 0.001 & 0.05 \\
\hline & III & 5 & 0.012 & 0.016 & 0.001 & 0.04 \\
\hline & I & 7 & 6.444 & 2.526 & 2.9 & 9.72 \\
\hline \multirow[t]{3}{*}{ B mg/L } & II & 12 & 2.74 & 1.752 & 1.06 & 6.55 \\
\hline & III & 5 & 6.7 & 1.157 & 5.48 & 8.44 \\
\hline & I & 7 & 0.023 & 0.025 & 0 & 0.065 \\
\hline \multirow[t]{3}{*}{$\mathrm{Cr} \mathrm{mg} / \mathrm{L}$} & II & 12 & 0.03 & 0.066 & 0.002 & 0.233 \\
\hline & III & 5 & 0.058 & 0.055 & 0 & 0.142 \\
\hline & I & 7 & 0.375 & 0.193 & 0.05 & 0.65 \\
\hline \multirow[t]{3}{*}{$\mathrm{PO}_{4} \mathrm{mg} / \mathrm{L}$} & II & 12 & 0.435 & 0.994 & 0.05 & 3.58 \\
\hline & III & 5 & 1.67 & 1.762 & 0.175 & 4.68 \\
\hline & I & 7 & 0.039 & 0.02 & 0.028 & 0.075 \\
\hline \multirow[t]{2}{*}{ BTEX mg/L } & II & 12 & 0.082 & 0.077 & 0.028 & 0.24 \\
\hline & III & 5 & 0.118 & 0.144 & 0.028 & 0.369 \\
\hline
\end{tabular}

On the other hand, cluster III wells recorded intermediate mean concentrations between clusters II and I. The distribution of wells and the clusters are shown in Area 2 wells are classified into three clusters (Figure 8). Cluster I includes seven wells (No. 1, 5, 14, 15, 23, 24, and 12), with 29.1\%. It has two sub-clusters, with the worst water quality as it attained the highest concentrations of cations, anions, TDS, TH, and conductivity (Table 6). Cluster II includes twelve wells (No. 10, 19, 2, 9, 18, 4, 8, 17, 6, 16, 11, and 20) with 50\%. It has the lowest concentration of cations, anions, TDS, TH, and conductivity among the Area 2 wells. The lowest number of Area 2 wells was included in Cluster III (No. 3, 22, 7, 13, and 21) with 5 wells which represented $20.8 \%$. This cluster has an intermediate concentration of cations, anions, TDS, TH, and conductivity between clusters II and I. 


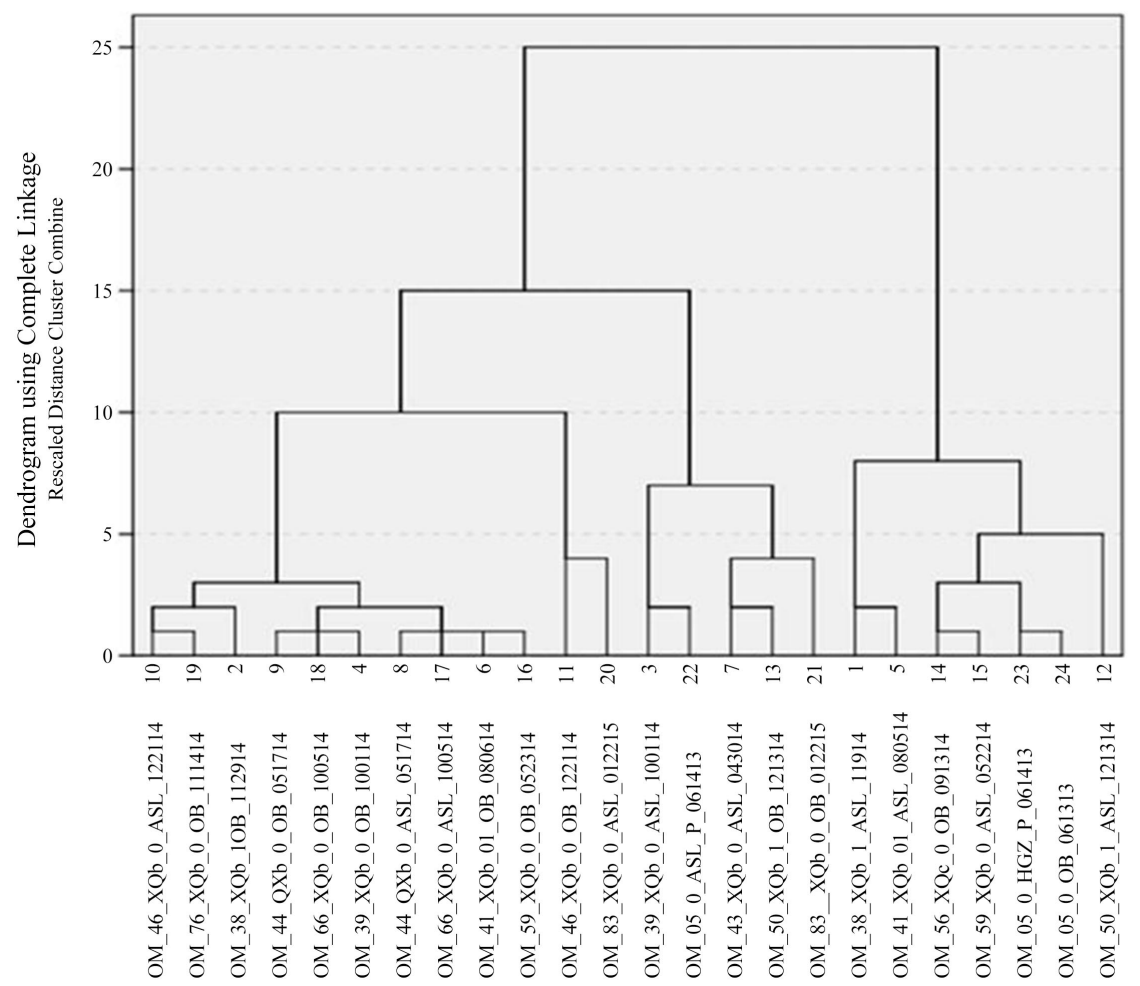

Figure 8. Hierarchical dendrogram cluster analysis of water quality parameters of the studied wells in Area 2.

\section{Conclusion}

Correlation analysis showed direct significant relationships between the different major anions and cations in Area 1. For example, $\mathrm{Ca}^{2+}, \mathrm{Mg}^{2+}, \mathrm{K}^{+}, \mathrm{Cl}^{-}$, $\mathrm{SO}_{4}^{2-}$, and others. Weak non-significant relationship recorded between nitrates correlation with major and measured trace elements did not reach the significance level. In Area 2, the $\mathrm{pH}$ shows a significant inverse correlation with each of TH, calcium, magnesium, sodium, potassium, nitrate ions, and a significant direct relationship with As. Additionally, nitrates and sulfate correlations with measured trace elements did not reach the significance level.

Factor analysis for Area 1 found that $76.8 \%$ of the variation in groundwater quality among the studied wells corresponded to the measured parameters. Sodium, chloride, calcite, strontium, magnesium, sulfate, and boron were the earliest, while iron and manganese in the last. Area 2 factor analysis found that $83.28 \%$ of the variation in groundwater quality among the studied wells corresponded to the measured parameters the $\mathrm{Na}^{+}, \mathrm{Cl}^{-}, \mathrm{Ca}^{2+}, \mathrm{K}^{+}, \mathrm{Mg}^{2+}$, and $\mathrm{NO}^{3-}$. The wells for Area 1 and Area 2 were classified into three water quality groups using cluster analysis.

\section{Ethical Approval and Informed Consent}

Not applicable. The study does not involve human or animal subjects. 


\section{Acknowledgements}

The authors express great gratitude to the Jordan oil shale company for facilitating and providing all the site data.

\section{Conflicts of Interest}

The authors declare no conflicts of interest regarding the publication of this paper.

\section{References}

Abdelhamid, G. (1997). Geology Map of Wadi Rajil Area Scale 1:50,000 Map Sheet No. 3453-IV. Amman, Jordan: Natural Resources Authority.

Abu Qudairah, M. (1997). The Geology of Wadi Attarat Umm Ghadran Area. Geological Mapping Division Bulletin 33, Amman, Jordan: Geology Directorate, NRA.

Al Hiyari, A., \& Halas, W. (2009). Geological Mapping of Qasr at Tuba Area Scale 1:100,000, Map Sheet No. 335-II. Amman, Jordan: Natural Resource Authority.

Al Hunjul, N. (1999). Geological Mapping of Qasr Al Harrana area Scale 1:50,000, Map Sheet, No. 335-II. Amman, Jordan: Natural Resource Authority.

American Public Health Association (APHA), American Water Works Association (AWWA), Water Environments Federation (WEF) (2013). Standard Method for the Examination of Water and Wastewater (22nd ed.) Washington DC.

Bender, F. (1974). Geology of Jordan. Berlin: Borntraeger.

Davis, J. G. (1973). Statistics and Data Analysis in Geology (pp. 473-524). New York: John Wiley and Sons, Inc.

El-Naqa, A., Al-Momani, M., Kilani, S., \& Hammouri, N. (2007). Groundwater Deterioration of Shallow Groundwater Aquifers Due to Overexploitation in Northeast Jordan. CLEAN: Soil, Air, Water, 35, 156-166. https://doi.org/10.1002/clen.200700012

Fadda, E. (1994). Geological Map of Wadi Al Ghadaf Area Scale 1:50,000, Map Sheet No. 3353-II. Amman, Jordan: Natural Resource Authority.

Fadda, E. (1997). Geological Map of Wadi ad Dabi Area Scale 1:50,000, Map Sheet No. 3353-III. Amman, Jordan: Natural Resource Authority.

Helena, B. A., Vega, M., Barrado, E., Pardo, R., \& Farnandez, L. (1999). A Case of Hydro Chemical Characterization of an Alluvial Aquifer Influenced by Human Activities. Water Air \& Soil Pollution, 112, 365-387. https://doi.org/10.1023/A:1005065422156

Helena, B., Pardo, R., Vega, M., Barrado, E., Fernandez, J. M., \& Fernandez, L (2000). Temporal Evolution of Groundwater Composition in an Alluvial Aquifer (Pisuerga River, Spain) by Principal Component Analysis. Water Research, 34, 807-816. https://doi.org/10.1016/S0043-1354(99)00225-0

Ibrahim, K. (1993). Geological Map of Azraq Area Scale1:50,000, Map Sheet No. 3353-I. Jordan.

Karthikeyan, P., Venkatachalapathy, R., \& Vennila, G. (2017). Multivariate Analysis for River Water Quality Assessment of the Cauvery River, Tamil Nadu, India. Indian Journal of Geo-Marine Sciences, 46, 785-790.

Obeidat, A. M., \& Rimawi, O. (2017). Characteristics and Genesis of the Groundwater Resources Associated with Oil Shale Deposits in the Azraq and Harrana Basins, Jordan. Journal of Water Resource and Protection, 9, 121-138. https://doi.org/10.4236/jwarp.2017.92010 
Postma, D., \& Appelo, C. A. J. (1999). Geochemistry, Groundwater and Pollution (2nd ed., pp. 375-537). Netherlands: A. A. Balkema.

Praus, P. (2005). Water Quality Assessment Using SVD Based Principal Component Analysis of Hydrological Data. Water SA, 31, 417-422. https://doi.org/10.4314/wsa.v31i4.5132

Quennel, A. M. (1956). Geological Map of Jordan (East of the Rift Valley) 1:250,000. Jordan: Department of Lands and Survey.

Saravanakumar, K., \& Ranjith Kumar, R. (2011). Analysis of Water Quality Parameters of Groundwater near Ambattur Industrial Area, Tamil Nadu, India. Indian Journal of Science and Technology, 4, 660-662. https://doi.org/10.17485/ijst/2011/v4i5.28

Shihab, A. S., \& Al-Rawi, S. M. (2005). Application of Factor Analysis as a Tool for Water Quality Management of Tigris River within Mosul City. Rafidain Journal of Science, 16, 56-64. https://doi.org/10.33899/rjs.2005.41398

Singh, K. P., Malik, A., Mohan, D., \& Sinha, S. (2004). Multivariate Statistical Techniques for the Evaluation of Spatial and Temporal Variations in Water Quality of Gomti River (India)-A Case Study. Water Research, 38, 3980-3992.

https://doi.org/10.1016/j.watres.2004.06.011

Vikal, P. (2009). Multivariant Analysis of Drinking Water Quality Parameters of Lake Pichhola in Udaipur, India. Biological Forum: An International Journal, 1, 86-91.

Zeng, X., \& Rasmussen, T. C. (2005). Multivariate Statistical Characterization of Water Quality in Lake Lanier in Georgia, USA. Journal of Environmental Quality, 34, 1980-1991. https://doi.org/10.2134/jeq2004.0337 